Jurnal Manajemen dan Kewirausahaan, Volume 9, Nomor 3, September 2018

ISSN 2086-5031

E-ISSN 2615-3300

DOI 10.31317

\title{
Pengaruh Profitabilitas, Leverage dan Risiko Investasi terhadap Price Earning Ratio pada Perusahaan Sub Sektor Food and Beverages di Bursa Efek Indonesia Periode 2012 - 2017
}

\author{
Oleh: \\ Syailendra Eka Saputra \\ Program Studi Pendidikan Ekonomi STKIP PGRI Sumatera Barat \\ saputrasyailendra@yahoo.com
}

\begin{abstract}
Abstrak
This study purpose to prove and analyze the effect of profitability, leverage and investment risk on price earnings ratio in food and beverages sub-sector companies in the Indonesia Stock Exchange. The number or size of the sample used in this study were 12 food and beverages subsector companies. Research period from 2012 to 2017. The analytical method used is panel data regression processed using Eviews 8.0. Based on the results of testing hypotheses that have been made it is found that profitability and leverage do not affect the price earning ratio of food and beverages sub-sector companies in the Indonesia Stock Exchange, while the investment risk has a significant effect on the price earning ratio of the food and beverages sub-sector on the Indonesia Stock Exchange.
\end{abstract}

\section{Kata Kunci: Profitabilitas, Leverage, Risiko Investasi dan Price Earning Ratio}

\section{PENDAHULUAN}

Pasar modal merupakan tempat bertemu antara pihak yang memiliki kelebihan modal dengan pihak yang membutuhkan modal. Pihak yang memiliki modal menyadari bahwa ketika mereka menyimpan dan menumpuk modal yang mereka miliki maka akan meningkatkan risiko kerugian. Oleh sebab itu salah cara yang dapat digunakan untuk meningkatkan keuntungan adalah dengan memanfaatkan kelebihan dana yang dimiliki dengan cara melakukan investasi. Kegiatan investasi dilakukan pada sejumlah sekuritas yang ditawarkan dipasar modal. Sekuritas yang ditawarkan mulai dari saham, obligasi, reksa dana dan sebagainya.

Bursa Efek Indonesia terdiri dari 9 sektor industri, dari sekian banyak sektor industri di Bursa Efek Indonesia manufaktur adalah sektor terbesar di Bursa Efek Indonesia. Menurut Irawan (2016) sektor manufaktur adalah kelompok perusahaan yang melakukan kegiatan usaha dengan proses produksi yang meliputi pengolahan bahanbaku menjadi bahan setengah jadi, dari bahan setengah jadi menjadi bahan jadi. Jumlah perusahaan yang tergabung dalam sektor manufaktur berjumlah 176 perusahaan yang tergabung dalam 18 sub sektor. Salah satu sub sektor yang berada dalam kelompok

Program Studi Manajemen Fakultas Ekonomi Unitas Padang 
Jurnal Manajemen dan Kewirausahaan, Volume 9, Nomor 3, September 2018

ISSN 2086-5031

E-ISSN 2615-3300

DOI 10.31317

perusahaan manufaktur adalah food and beverages.

Menurut Zooneld (2017) sub sektor food and beverages adalah kelompok perusahaan yang melakukan kegiatan usaha untuk menghasilkan produk makanan dan minuman. Sektor food and beverages menjadi salah satu sub sektor unggalan di Bursa Efek Indonesia. Sub sektor tersebut didukung oleh perusahaan dengan kinerja terbaik. Pencapaian yang diperoleh masing masing perusahaan dalam menghasilkan kinerja tidak terlepas dari kemampuan perusahaan dalam mendorong kestabilan penjualan.

Menurut Pradana (2018) kestabilan nilai penjualan perusahaan di sub sektor food and beverages terjadi karena produk yang dijual adalah aneka makanan dan minuman, yang memiliki harga jual yang relatif terjangkau dan tidak begitu terpengaruh dampak inflasi ataupun resesi ekonomi, akibatnya perusahaan yang tergabung dalam sub sektor makanan dan minuman memiliki kinerja yang cukup baik dan memberikan jaminan keuntungan yang lebih optimal bagi pemegang saham, oleh sebab itu sub sektor food and beverages menjadi sub sektor unggulan di Bursa Efek Indonesia hingga saat ini. Jumlah perusahaan yang berada didalam sub sektor food and beverages terus bertambah hingga saat ini. Pada tahun 2014 jumlah perusahaan dalam sub sektor food and beverages hanya berjumlah 21 perusahaan, ditahun 2015 meningkat menjadi 23 perusahaan, penambahan jumlah perusahaan masih terus terjadi hingga tahun 2017 yaitu menjadi 29 perusahaan.
Sektor food and bevarages merupakan salah satu sub sektor dengan nilai capitalisasi pasar yang tinggi, hal tersebut terjadi karena pada umumnya investor sangat menyukai prospek perkembangan investasi di sub sektor tersebut, yang menjadi permasalahan saat ini adalah, sebagian besar investor menjadi sangat keberatan untuk membeli saham perusahaan yang berada pada sub sektor food and beverages, karena harga yang ditawarkan terlalu mahal. Salah satu perusahaan dengan nilai pasar saham tertinggi adalah PT Multibintang Tbk, untuk mendapatkan satu lembar saham PT Multibintang investor harus mengeluarkan uang tunai hingga $\mathrm{Rp} 350.000$, nilai yang dikeluarkan investor bisa membeli satu lot (1000 lembar) saham perusahaan lapis tiga di Bursa Efek Indonesia, akibatnya sangat kesulitan bagi pemegang saham untuk menjual saham yang mereka miliki, hal tersebut menunjukan likuiditas saham perusahaan food and beverages relatif rendah.

Perusahaan dalam sub sektor food and beverages berjumlah lebih kurang 25 perusahaan. Menurut Rahman (2017) mengungkapkan bahwa sub sektor food and beverage merupakan salah satu sub sektor terbaik di Bursa Efek Indonesia, hal tersebut didorong oleh terus meningkatnya performance beberapa perusahaan dalam sektor tersebut, selain itu tercatat sebanyak 7 perusahaan dalam sub sektor food and beverages merupakan anggota kelompok perusahaan teraktif di Bursa Efek Indonesia sedangkan beberapa lainnya mencatatkan diri sebagai perusahaan dengan konsistensi laba

Program Studi Manajemen Fakultas Ekonomi Unitas Padang 
Jurnal Manajemen dan Kewirausahaan, Volume 9, Nomor 3, September 2018

ISSN 2086-5031

E-ISSN 2615-3300

DOI 10.31317

terbaik dari tahun 2011 sampai dengan 2017 yang lalu.

Keberhasilan perusahaan yang berada pada sub sektor food and beverages untuk menjaga konsistensi kinerja keuangan yang mereka miliki akan mendorong meningkatnya nilai perusahaan. Menurut Sartono (2010) nilai perusahaan menunjukan sejauhmana perusahaan dapat menjaga kinerja keuangan yang mereka hasilkan dan menjaga kesejahteraan investor, sehingga mempengaruhi pergerakan harga saham yang diperoleh.Salah satu indikator penting yang dapat digunakan investor dalam mengukur nilai perusahaan adalah price earning ratio (PER).

Nilai perusahaan dapat diamati dari pergerakan harga saham, ketika harga saham perusahaan mengalami peningkatan menunjukan nilai perusahaan semakin tinggi.Secara teori konsep nilai perusahaan sangat berkaitan dengan teori signaling. Didalam teori tersebut nilai akan terbentuk ketika seluruh investor yang berinvestasi pada setiap perusahaan mampu menggunakan signel atau informasi untuk memperoleh keuntungan, seperti keuntungan jangka pendek yang return atau keuntungan jangka panjang dalam bentuk dividen (Ross, 2010).

Menurut Tandelilin (2010) nilai perusahaan menunjukan konsistensi perusahaan dalam mengelola kinerja keuangan yang mereka miliki sekaligus menciptakan kemakmuran bagi pemegang saham yang berada didalam perusahaan. Nilai perusahaan dapat diamati dari kelayakan harga saham yang dimiliki perusahaan.Semakin tinggi harga saham menunjukan nilai perusahaan semakin meningkat.

Dalam menentukan nilai perusahaan dapat digunakan sejumlah pengukuran diantaranya adalah Tobins $Q$, Price to book value, price earning ratio dan harga saham.Pada penelitian ini peneliti memilih menggunakan price earning ratio untuk mengukur nilai perusahaan.

Price earning ratio merupakan salah satu variabel yang dapat digunakan investor untuk memutuskan kapan mereka akan membeli saham atau mencari saham perusahaan lain yang lebih rendah. Peningkatan price earning ratio sejalan dengan peningkatan harga saham, semakin tinggi nilai price earning ratio menggambarkan terjadi peningkatan harga saham. Peningkatan price earning ratio akan meningkatkan risiko dalam berinvestasi, khususnya risiko yang berasal dari luar perusahaan.

Semakin tinggi nilai PER yang dimiliki perusahaan akan mendorong meningkatnya harga saham, bahkan dapat memicu pertumbuhan yang abnormal dari harga saham, sehingga mengurangi tingkat likuiditas saham yang dimiliki perusahaan. Peningkatan nilai PER tentu tidak terbentuk dengan sendirinya akan tetapi dapat dipengaruhi oleh sejumlah variabel. Menurut Tandelilin (2010) perubahan PER dapat dipengaruhi oleh kebijakan dividen dan set kesempatan investasi yang dimiliki perusahaan.

Selain itu PER yang terlalu tinggi akan menyebabkan likuiditas saham mengalami penurunan, keadaan tersebut terjadi pada kasus PT Multi Bintang

Program Studi Manajemen Fakultas Ekonomi Unitas Padang 
Jurnal Manajemen dan Kewirausahaan, Volume 9, Nomor 3, September 2018

ISSN 2086-5031

E-ISSN 2615-3300

DOI 10.31317

Indonesia Tbk. Dari tahun 2011 sampai dengan 2015 yang lalu PT Multibintang memiliki harga saham yang sangat tinggi yaitu Rp 350.000 per lembar saham diakhir Desember 2015, akibatnya ditahun triwulan pertama tahun 2016 perusahaan tersebut tidak mengalami penambahan jumlah dana dari pihak ketiga mengingat harga saham yang ditawarkan terlalu tinggi, akibatnya manajemen melakukan stock split pada Agustus 2016, untuk menurunkan nilai PER dan harga saham yang terlalu tinggi, sehingga Desember 2016 harga perlembar saham PT Multi Bintang Tbk dihargai Rp 3250 per lembar saham.

Bagi investor meningkatnya PER perusahaan akan mempengaruhi keputusan mereka dalam berinvestasi. Ketika PER mengalami peningkatan harga saham yang terbentuk akan semakin tinggi, dan risiko investasi semakin besar, keadaan tersebut akan mempengaruhi psikologis investor sehingga akan dapat mempengaruhi likuiditas saham perusahaan dalam jangka panjang.

Peningkatan dan penuruna price earning ratio dapat dipengaruhi oleh sejumlah saah satunya adalah profiabilitas. Profitabilitas merupakan rasio yang menunjukan kemampuan perusahaan dalam menghasilkan laba (Sartono, 2010). Semakin tinggi kemampuan perusahaan dalam menghasilkan laba akan mendorong menguatnya harga saham perusahaan, ketika nilai harga saham perusahaan mengalami peningkatan menunjukan nilai perusahaan juga terus menguat. Berdasarkan uraian ringkas tersebut peneliti menduga bahwa profitabilitas berpengaruh terhadap nilai perusahaan yang diukur dengan price earning ratio.

Pada peneitian Mabruroh dkk (2015) menemukan bahwa profitabilitas yang diukur dengan return on assets berpengaruh positif terhadap price earning ratio. Permanasari(2017) menemukan bahwa profitabilitas yang diukur dengan return on assets berpengaruh positif terhadap nilai perusahaan yang diukur dengan price earning ratio. Temuan yang diperoleh menunjukan semakin tinggi kemampuan perusahaan dalam menghasilkan laba akan meningkatkan nilai perusahaan yang terlihat dari pergerakan harga pasar saham yang dimiliki masing masing perusahaan.

Disamping profitabilitas perubahan nilai perusahaan dapat dipengaruhi oleh leverage atau solvabilitas. Menurut Brigham dan Houston (2009) leverage merupakan rasio yang menunjkan kemampuan dari perusahaan untuk mengelola sumber dana yang berasal dari hutang. Dalam rangka meningkatkan nilai perusahaan, hutang memiliki peranan yang besar, selama penggunaan hutang dapat dikelola dengan baik, akan tetapi ketika perusahaan terlalu bergantung pada hutang maka nilai perusahaan akan menurun karena besarnya nilai hutang akan meningkatkan risiko bagi perusahaan khususnya yang berhubungan dengan distress atau masalah keuangan.

Arif (2012) ditemukan bahwa leverage yang diukur dengan debt to equity ratio berpengaruh negatif terhadap price earning ratio yang dimiliki perusahaan manufaktur di Bursa Efek Indonesia. Hasil penelitian Alfi dan Zafarzadeh (2016) menemukan bahwa leverageperusahaan yang

Program Studi Manajemen Fakultas Ekonomi Unitas Padang 
Jurnal Manajemen dan Kewirausahaan, Volume 9, Nomor 3, September 2018

ISSN 2086-5031

E-ISSN 2615-3300

DOI 10.31317

diukur dengan debt to equity ratio berpengaruh negatif terhadap price earning ratio perusahaan publik di Turki. Besarnya posisi hutang menciptakan ketakutan pemegang saham untuk terus berinvestasi dalam perusahaan, karena dengan hutang yang tinggi akan memperbesar kemungkinan bagi perusahaan untuk mengalami permasalahan keuangan (distress), akibatnya nilai price earning ratio yang dimiliki perusahaan relatif mengalami penurunan.

Disampin instruman yang berasal dari kinerja perusahaan, perubahan price earning ratio jug dapat dipengaruhi oleh risiko investasi. Menurut Tandelilin (2010) risiko adalah selisih total keuntungan yang diharapkan dengan yang diterima investor. Dalam mengukur risiko diukur dengan menggunakan beta saham. Secara teori risiko berpengaruh positif terhadap keuntungan atau pun nilai perusahaan. Permasalahannya adalah tidak banyak investor yang menyukai risiko, mereka cenderung menghindari risiko.

Saputra dkk (2016) ditemukan bahwa risiko investasi berpengaruh positif terhadap price earning ratio perusahaan manufaktur perusahaan go public di Bursa Efek Indonesia. Hasil penelitian yang konsisten diperoleh oleh Astuti dan Efni (2012) yang menemukan bahwa risiko berpengaruh positif terhadap price earning ratio pada perusahaan manufaktur di Bursa Efek Indonesia. Hasil penelitian yang tidak konsisten diperoleh oleh Arif (2012) yang meneukan bahwa risiko investasi tidak berpengaruh signifikan terhadap price earning ratio yang dimiiki perusahaan.

\section{Tujuan Penelitian}

Berdasarkan kepada perumusan masalah, maka tujuan dilaksanakannya penelitian ini adalah untuk menganalisis dan membuktikan secara empiris pengaruh profitabiltas, leverage, dan risiko investasi dalam meningkatkan atau menurunkan nilai perusahaan yang diukur dengan price earning ratio pada perusahaan sub sektor food and beverages di Bursa Efek Indonesia tahun $2012-2017$

\section{Pengembangan Hipotesis}

\section{Pengaruh Profitabilitas Terhadap PER}

Sartono (2010) menyatakan bahwa profitabilitas merupakan rasio yang menunjukan kemampuan perusahaan dalam menghasilkan laba. Semakin tinggi kemampuan perusahaan dalam menghasilkan laba merupakan berita positif bagi pelaku pasar sehingga mendorong meningkatnya harga saham yang sejalan dengan peningkatan price earning ratio yang dimiliki sebuah perusahaan

Mabruroh dkk (2015) menemukan bahwa profitabilitas yang diukur dengan return on assets berpengaruh positif terhadap price earning ratio. Peningkatan laba merupakan informasi positif bagi pelaku pasar yang mendorong meningkatnya mekanisme permintaan dan penawaran terhadap saham, sehingga mendorong peningkatan price earning ratio yang dimiliki perusahaan.. 
Jurnal Manajemen dan Kewirausahaan, Volume 9, Nomor 3, September 2018

ISSN 2086-5031

E-ISSN 2615-3300

DOI 10.31317

Permanasari (2017) menemukan bahwa profitabilitas yang diukur dengan return on assets berpengaruh positif terhadap nilai perusahaan yang diukur dengan price earning ratio. Laba yang terus meningkat merupakan informasi positif yang akan mendorong peningkatan price earning ratio. Sesuai dengan uraian ringkas tersebut diajukan sebuah hipotesis yang akan dibuktikan yaitu:

$\mathrm{H}_{1} \quad$ Profitabilitas berpengaruh positif terhadap price earning ratio pada perusahaan food and beverages di Bursa Efek Indonesia

\section{Pengaruh Leverage Terhadap Price Earning Ratio}

Menurut Palepu (2009) leverage atau solvabilitas merupakan rasio keuangan yang menunjukan kemampuan perusahaan dalam mengelola sumber dana yang berasal dari hutang. Rasio tersebut menunjukan seberapa efektif aliran dana yang bersumber dari hutang untuk mendorong meningkatnya kinerja perusahaan. Ketika perusahaan mampu mengelola dana yang bersumber dari hutang dengan baik maka akan mendorong menguatnya nilai perusahaan yang ditunjukan dengan semakin meningkatnya nilai price earning ratio yang dimiliki perusahaan. Sesuai dengan uraian teori yang telah dijelaskan dapat disimpulkan bahwa leverage berpengaruh negatif terhadap price earning ratio yang dimiliki perusahaan.

$$
\text { Hasil penelitian Arif (2012) }
$$
ditemukan bahwa leverage yang diukur dengan debt to equity ratio berpengaruh negatif terhadap price earning ratio yang dimiliki perusahaan manufaktur di Bursa Efek Indonesia. Keadaan tersebut menunjukan ketika posisi hutang yang dimiliki perusahaan mengalami peningkatan maka akan menciptakan kekhwatiran pemegang saham atau pun investor diluar perusahaan, akibatnya nilai price earning ratio akan menurun, penurunan tersebut sejalan dengan terkoreksinya harga saham perusahaan.

Alfi dan Zafarzadeh (2016) menemukan leverage perusahaan yang diukur dengan debt to equity ratio berpengaruh negatif terhadap price earning ratio perusahaan public di Turki. Besarnya posisi hutang menciptakan ketakutan pemegang saham untuk terus berinvestasi dalam perusahaan, karena dengan hutang yang tinggi akan memperbesar kemungkinan bagi perusahaan untuk mengalami permasalahan keuangan (distress),. Sesuai dengan uraian hasil penelitian tersebut diajukan sebuah hipotesis yaitu:

$\mathrm{H}_{2}$ Leverage berpengaruh negatif terhadap PER pada perusahaan food and beverages di Bursa Efek Indonesia

\section{Pengaruh Risiko Investasi Terhadap Price Earning Ratio}

Menurut Tandelilin (2010) risiko investasi adalah selisih antara keuntungan yang diharapkan dengan keuntungan yang diterima. Ketika risiko yang harus dikelola perusahaan semakin tinggi maka kecenderungan keuntungan yang akan

Program Studi Manajemen Fakultas Ekonomi Unitas Padang 
diperoleh akan semakin tinggi. Sesuai dengan uraian teori tersebut peneliti menduga bahwa risiko investasi saham yang dihadapi masing masing investor berpengaruh positif terhadap price earning ratio yang dimiliki sebuah perusahaan.

Hasil penelitian Saputra dkk (2016) ditemukan bahwa risiko investasi berpengaruh positif terhadap price earning ratio perusahaan manufaktur perusahaan go public di Bursa Efek Indonesia. Hasil yang diperoleh menunjukan bahwa semakin tinggi risiko investasi yang dihadapi investor akan semakin mendorong menguatnya nilai perusahaan yang diamati dari price earning ratio. Keberanian investor dalam mengelola risiko yang besar akan mendorong meningkatnya keuntungan yang diperoleh dalam berinvestasi. Sesuai dengan uraian tersebut diajukan hipotesis yang berbunyi:

$\mathrm{H}_{3} \quad$ Risiko investasi berpengaruh positif terhadap PER pada perusahaan food and beverages di Bursa Efek Indonesia

\section{Model Kerangka Konseptual}

Berdasarkan landasan teori dan pengembangan hipotesis yang telah dijelaskan maka dapat dibuat sebuah model kerangka konseptual terlihat pada gambar 1 dibawah ini:

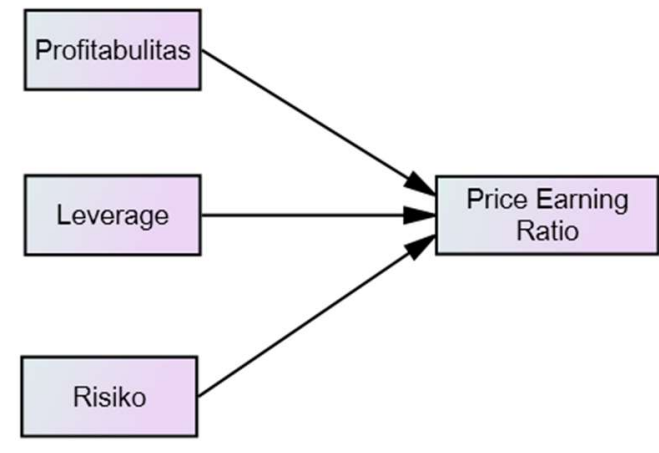

Gambar 1

\section{Model Kerangka Konseptual}

\section{METODE PENELITIAN}

\section{Populasi dan Sampel}

Populasi merupakan kesatuan atribut yang saling bekerja sama untuk mencapai satu tujuan. Pada penelitian ini yang menjadi populasi adalah seluruh perusahaan food and beverages yang go public di Bursa Efek Indonesia dari tahun 2012 sampai dengan 2017 yang lalu.

Pada penelitian ini yang menjadi sampel adalah seluruh perusahaan yang bergerak pada sub sektor food and beverages di Bursa Efek Indonesia yaitu berjumlah 16 perusahaan. Mengingat jumlah populasi relatif kecil, maka seluruh populasi digunakan sebagai sampel. Mengingat ukuran sampel yang kecil maka metode pengambilan sampel yang digunakan adalah purposive sampling, didalam metode tersebut peneliti perusahaan yng dijadikan sampel adalah perusahaan food and beverages yang mempublikasikan laporan keuangan secara lengkap sepanjang tahun 2012 sampai 2017.

Program Studi Manajemen Fakultas Ekonomi Unitas Padang 


\section{Definisi Operasional dan Pengukuran Variabel}

\section{Variabel Dependen}

\section{Price Earning Ratio}

Menurut Ross (2010) price earning ratio menunjukan besarnya keuntungan per saham yang diterima investor setelah melaksanakan aktifitas investasi. Secara umum price earning ratio dapat dicari dengan menggunakan rumus:

$$
P E \mathrm{R}=\frac{\text { Harga Saham }}{\text { Laba per Lembar Saham }}
$$

\section{Variabel Independen}

Secara umum variabel independen yang digunakan dalam penelitian ini adalah sebagai berikut:

\section{Profitabilitas}

Sartono (2010) mengungkapkan profitabilitas merupakan rasio yang menunjukan kemampuan perusahaan dalam menghasilkan laba. Pada penelitian ini profitabilitas diukur dengan menggunakan return on assets yang dapat dicari dengan menggunakan rumus sebagai berikut:

\section{Leverage}

$$
R O A=\frac{\text { Laba Bersih }}{\text { Total Assets }} \times 100 \%
$$


Jurnal Manajemen dan Kewirausahaan, Volume 9, Nomor 3, September 2018

ISSN 2086-5031

E-ISSN 2615-3300

DOI 10.31317

\section{Pengujian Normalitas}

Pada model penelitian saat ini pengujian normalitas dilakukan dengan menggunakan bantuan uji Jurgue Bera Test memalui model residual Berdasarkan hasil pengujian normalitas yang telah dilakukan diperoleh ringkasan hasil terlihat pada Gambar 2 dibawah ini;
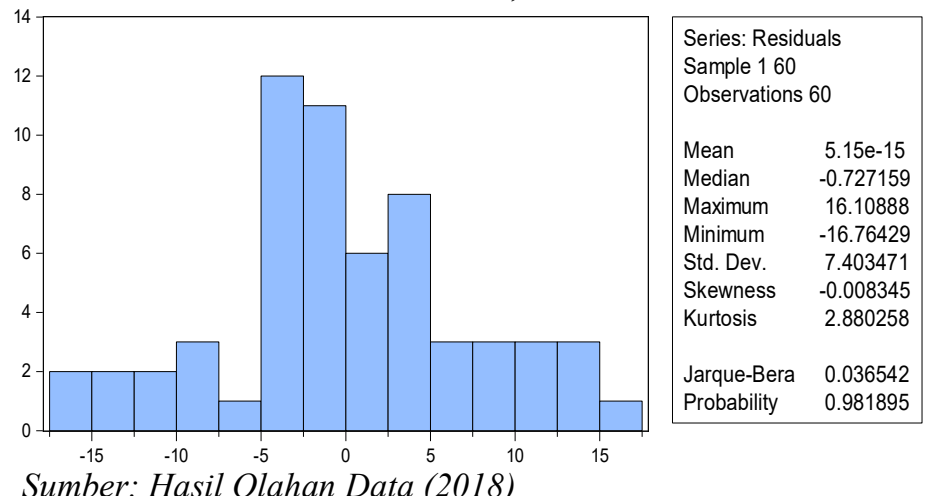

Gambar 2

\section{Hasil Pengujian Normalitas Residual}

Berdasarkan hasil pengujian normalitas yang telah dilakukan terlihat nilai probability yang diperoleh telah berada diatas atau sama dengan 0,05 sehingga dapat disimpulkan bahwa seluruh variabel penelitian yang telah dibentuk kedalam sebuah model regression cross section berdistribusi normal, oleh sebab itu tahapan pengolahan data lebih lanjut dapat dilaksanakan.

\section{Pengujian Persyaratan Model}

Sebelum dilakukan pemilihan model regresi panel maka terlebih dahulu dilakukan pengujian pra syarat regresi panel yaitu:

\section{Pengujian Chow Test (Fixed Effect Model)}

Penguijan Chow test dilakukan untuk menentukan apakah model regresi panel yang digunakan lebih menggunakan fixed effect model atau model yang lain. Berdasarkan hasil pengujian chow test diperoleh ringkasan terlihat pada Tabel 1 dibawah ini:

\section{Tabel 1}

Hasil Pengujian Chow Test

\begin{tabular}{|l|c|}
\hline \multicolumn{1}{|c|}{ Effect Test } & Probability \\
\hline Cross-section F & 0.0052 \\
\hline Cross-section Chi-square & 0.0005 \\
\hline
\end{tabular}

Sumber: Hasil Olahan Data (2018)

Berdasarkan hasil pengujian terlihat bahwa nilai pengujian Cross-section $F$ menghasilkan nilai probability sebesar 0,0052. Nilai probability yang dihasilkan berada dibawah tingkat kesalahan 0,05 sehingga dapat disimpulkan penggunaan fixed effect model sebagai alat analisis data adalah tepat.

\section{Pengujian Hausman Test (Random Effect Model)}

Pengujian Hausman Test dilakukan untuk memastikan bahwa pembentukan analisis model regresi panel lebih tepat dilakukan dengan memggunakan model random effect model. Berdasarkan hasil pengolahan data yang telah dilakukan diperoleh ringkasan hasil terlihat pada Tabel 2 dibawah ini

Program Studi Manajemen Fakultas Ekonomi Unitas Padang 
Jurnal Manajemen dan Kewirausahaan, Volume 9, Nomor 3, September 2018

ISSN 2086-5031

E-ISSN 2615-3300

DOI 10.31317

Tabel 2

Hasil Pengujian Hausman Test

\begin{tabular}{|c|c|}
\hline Effect Test & Probability \\
\hline Cross-section random & 0.129 \\
\hline
\end{tabular}

Sumber: Hasil Olahan Data (2018)

Berdasarkan hasil pengujian terlihat bahwa nilai pengujian Cross-section random menghasilkan nilai probability sebesar 0,129. Nilai probability yang dihasilkan berada diatas tingkat kesalahan 0,05 sehingga dapat disimpulkan penggunaan random effect model sebagai alat analisis data juga dianjurkan dalam penelitian ini.

\section{Hasil Pengujian Hipotesis}

Berdasarkan hasil pengujian hipotesis yang telah dilakukan diperoleh ringkasan hasil terlihat dalam tabel 3 dibawah ini yaitu:

\section{Tabel 3}

Ringkasan Hasil Pengujian Hipotesis

\begin{tabular}{|l|r|c|c|}
\hline $\begin{array}{c}\text { Variabel } \\
\text { Penelitian }\end{array}$ & $\begin{array}{c}\text { Koefisien } \\
\text { Regresi }\end{array}$ & Prob & Kesimpulan \\
\hline Konstanta & 15.867 & - & - \\
\hline ROA & 0.476 & 0.000 & Signifikan \\
\hline DER & 0.251 & 0.002 & Signifikan \\
\hline RISK & 1.024 & 0.322 & $\begin{array}{c}\text { Tdk } \\
\text { Signifikan }\end{array}$ \\
\hline \multicolumn{3}{|c|}{0.974} \\
\hline \multicolumn{3}{|c|}{ F-prob 0.000} \\
\hline \multicolumn{4}{|c|}{} \\
\hline
\end{tabular}

Sumber: Hasil Olahan Data (2018)

Berdasarkan ringkasan hasil pengujian hipotesis yang telah dilakukan dapat dibuat kedalam persamaan regresi sebagai berikut:

$$
\mathrm{Y}=15.867+0.476 \mathrm{X}_{1}+0.251 \mathrm{X}_{2}+1.024 \mathrm{X}_{4}
$$

Sesuai ringkasan hasil pengujian hipotesis diketahui nilai koefisien determinasi yang dihasilkan adalah sebesar 0.754. Hasil yang diperoleh menunjukan bahwa return on assets, debt to equity ratio dan risiko investasi mampu memberikan variasi kontribusi dalam mempengaruhi nilai perusahan yang diukur dengan price earning ratio sebesar $97.40 \%$ sedangkan sisanya sebesar $2.60 \%$ lagi dipengaruhi oleh variabel lain yang tidak digunakan di dalam penelitian ini.

Pada ringkasan juga terlihat hasil pengujian F-statistik dengan nilai probability sebesar 0,000. Pada tahapan pengolahan data digunakan tingkat kesalahan sebesar 0,05. Hasil yang diperoleh menunjukan bahwa probability sebesar 0,000 berada dibawah 0.05 maka keputusannya adalah Ho ditolak dan Ha diterima maka dapat disimpulkan bahwa return on assets, debt to equity ratio, dan risiko investasi secara bersama sama berpengaruh terhadap price earning ratio. Temuan yang diperoleh juga menunjukan bahwa model regresi yang telah dibentuk dinyatakan tepat atau layak.

Sesuai dengan hasil pengujian hipotesis pertama ditemukan bahwa return on assets memiliki koefisien regresi bertanda positif sebesar 0.476.Pada tahapan pengujian t-statistik diperoleh nilai probability sebesar 0,000. Pada tahapan pengolahan data digunakan tingkat kesalahan sebesar 0,05. Hasil yang diperoleh tersebut menunjukan

Program Studi Manajemen Fakultas Ekonomi Unitas Padang 
Jurnal Manajemen dan Kewirausahaan, Volume 9, Nomor 3, September 2018

ISSN 2086-5031

E-ISSN 2615-3300

DOI 10.31317

bahwa nilai probability sebesar 0.000 berada dibawah tingkat kesalahan sebesar 0,05 maka keputusannya adalah Ho ditolak dan $\mathrm{Ha}$ diterima sehingga dapat disimpulkan bahwa profitabilitas yang diuku return on assets berpengaruh positif dan signifikan terhadap nilai perusahaan sub sektor food and beverages di Bursa Efek Indonesia.

Pada tahapan pengujian hipotesis kedua dengan menggunakan variabel debt to equity ratio dieproleh nilai koefisien regresi bertanda positif sebesar 0.251 . Nilai koefisien yang diperoleh diperkuat dengan nilai probability sebesar 0.002 . Proses pengolahan data digunakan tingkat kesalahan sebesar 0,05. Hasil yang diperoleh menunjukan bahwa nilai probability sebesar 0,002 berada jauh dibawah 0,05 maka keputusannya adalah Ho ditolak dan Ha diterima sehingga dapat disimpulkan bahwa leverage yang diukur dengan debt to equity ratio berpengaruh positif dan signifikan terhadp nilai perusahaan pada perusahaan sub sektor food and beverages di Bursa Efek Indonesia.

Pada tahapan pengujian hipotesis ketiga dengan menggunakan variabel investment opportunity set. Diperoleh nilai koefisien regresi bertanda positif sebesar 0.488.Nilai koefisien yang diperoleh diperkuat dengan nilai probability sebesar 0.121. Pada tahapan pengolahan data digunakan tingkat kesalahan sebesar 0,05. Hasil yang diperoleh menunjukan bahwa nilai probability sebesar 0,121 berada diatas 0,05 maka keputusannya adalah Ho diterima dan Ha ditolak sehingga dapat disimpulkan bahwa investment opportunity set tidak berpengaruh signifikan terhadap nilai perusahaan pada perusahaan sub sektor food and beverages di Bursa Efek Indonesia.

Berdasarkan hasil pengujian hipotesis keempat dengan menggunakan variabel risiko investasi. Diperoleh nilai koefisien regresi bertanda positif sebesar 1.024. Nilai koefisien yang diperoleh diperkuat dengan nilai probability sebesar 0.322 . Pada tahapan pengolahan data digunakan tingkat kesalahan sebesar 0,05. Hasil yang diperoleh menunjukan bahwa nilai probability sebesar 0,322 berada diatas 0,05 maka keputusannya adalah Ho diterima dan Ha ditolak sehingga dapat disimpulkan bahwa risiko investasi tidak berpengaruh signifikan terhadap nilai perusahaan pada perusahaan sub sektor food and beverages di Bursa Efek Indonesia.

\section{Pembahasan}

\section{Pengaruh Profitabilitas Terhadap PER}

Berdasarkan hasil pengujian hipotesis pertama ditemukan bahwa return on assets berpengaruh positif dan signifikan terhadap price earning ratio pada perusahaan sub sektor food and beverages di Bursa Efek Indonesia. Temuan yang diperoleh pada tahapan pengujian hipotesis pertama sejalan dengan hasil penelitian Mabruroh dkk (2015) dan Permanasari (2017) menemukan bahwa profitabilitas yang diukur dengan return on assets berpengaruh positif terhadap price earning ratio. Semakin tinggi kemampuan perusahaan dalam menghasilkan laba akan menciptakan sentiment positif dari pelaku pasar terhadap prospek perkembangan perusahaan, sehingga mendorong mereka untuk membeli saham yang ditawarkan perusahaan, dampaknya adalah terjadinya

Program Studi Manajemen Fakultas Ekonomi Unitas Padang 
Jurnal Manajemen dan Kewirausahaan, Volume 9, Nomor 3, September 2018

ISSN 2086-5031

E-ISSN 2615-3300

DOI 10.31317

kenaikan harga saham. Kenaikan harga pasar saham sejalan dengan kenaikan price earning ratio yang dimiliki perusahaan.

\section{Pengaruh Leverage Terhadap PER}

Berdasarkan hasil pengujian hipotesis kedua ditemukan bahwa leverage yang diukur dengan debt to equity ratio berpengaruh positif dan signifikan terhadap price earning ratio pada perusahan sub sektor food and beverages di Bursa Efek Indonesia. Temuan yang diperoleh tersebut Temuan yang diperoleh pada tahapan pengujian hipotesis kedua konsisten dengan hasil penelitian yang dilakukan oleh Arif (2012) serta hasil penelitian Alfi dan Zafarzadeh (2016) ditemukan bahwa leverage yang diukur dengan debt to equity ratio berpengaruh negatif terhadap price earning ratio yang dimiliki perusahaan manufaktur di Bursa Efek Indonesia. Keadaan tersebut menunjukan ketika posisi hutang yang dimiliki perusahaan mengalami peningkatan maka akan menciptakan kekhwatiran pemegang saham atau pun investor diluar perusahaan, akibatnya nilai price earning ratio akan menurun, penurunan tersebut sejalan dengan terkoreksinya harga saham perusahaan. perusahaan relatif mengalami penurunan

\section{Pengaruh Risiko Terhadap PER}

Hasil pengujian hipotesis keempat
ditemukan bahwa risiko investasi
berpengaruh tidak signifikan terhadap price
earning ratio pada perusahaan sub sektor
food and beverages di Bursa Efek Indonesia.

Temuan yang diperoleh pada tahapan pengujian hipotesis keempat tidak sejalan dengan hasil penelitian yang dilakukan oleh Tandelilin (2010) serta penelitian Saputra dkk (2016) risiko investasi adalah selisih antara keuntungan yang diharapkan dengan keuntungan yang diterima. Semakin tinggi risiko akan sejalan dengan kenaikan nilai price earning ratio. Ketika risiko yang harus dikelola perusahaan semakin tinggi maka kecenderungan keuntungan yang akan diperoleh akan semakin tinggi. Sesuai dengan uraian teori tersebut peneliti menduga bahwa risiko investasi saham yang dihadapi masing masing investor berpengaruh positif terhadap price earning ratio yang dimiliki sebuah perusahaan.

\section{PENUTUP}

\section{Kesimpulan}

Sesuai dengan analisis dan pembahasan hasil pengujian hipotesis yang telah dilakukan dapat diajukan beberapa kesimpulan penting yang merupakan jawaban dari permasalahan yang diajukan dalam penelitian ini.

1. Profitabilitas berpengaruh positif dan signifikan terhadap nilai perusahaan yang diukur dengan price earning ratio pada perusahaan sub sektor food and beverages di Bursa Efek Indonesia.

2. Leverage berpengaruh positif dan signifikan terhadap nilai perusahaan yang diukur dengan price earning ratio pada perusahaan sub sektor food and beverages di Bursa Efek Indonesia. 
3. Risiko investasi saham tidak berpengaruh signifikan terhadap nilai perusahaan yang diukur dengan price earning ratio pada perusahaan sub sektor food and beverages di Bursa Efek Indonesia.

\section{Implikasi}

Berdasarkan kepada kesimpulan hasil pengujian hipotesis yang telah dijelaskan maka dapat diajukan beberapa implikasi penting yaitu sebagai berukut:

1. Bagi manajemen perusahaan diharapkan untuk terus berupaya meningkatkan kemampuan mereka dalam menghasilkan laba yaitu dengan cara menciptakan efektifitas dalam pengelola aset dan sumber dana, meningkatnya kemampuan perusahaan dalam menghasilkan laba akan menciptakan peningkatan nilai perusahaan yang ditandai dengan menguatnya harga saham perusahaan.

2. Bagi manajemen perusahaan di sarankan untuk lebih berhati hati dalam memafaatkan sumber dana khususnya yang berasal dari hutang serta mencoba untuk tidak bergantung pada hutang dan berusaha menggunakan sumber dana yang berasal dari dalam perusahaan saran tersebut penting untuk mendorong meningkatnya harga saham perusahaan yang menandakan meningkatnya nilai perusahaan.

Saran
Berdasarkan kepada keterbatasan penelitian maka diajukan beberapa saran yang dapat memberikan manfaat positif bagi:

1. Peneliti dimasa mendatang disarankan untuk menambah ukuran sampel dengan memperbanyak sub sektor usaha yang digunakan, semakin banyak ukuran sampel yang digunakan akan mendorong meningkatnya ketepatan dan akurasi hasil penelitian yang diperoleh.

2. Peneliti dimasa mendatang disarankan untuk mencari karakterisitk perusahaan yang sama sehingga sangat diperlukan bagi peneliti dimasa mendatang untuk menggunakan metode pengambilan sampel yang berbeda. Selaon itu disarankan untuk menambahkan minimal satu varaibel baru yang dapat mempengaruhi price earning ratio yang belum digunakan dalam penelitian ini seperti total assets turnover, dividend payout ratio, net profit margin dan sebagainya. Saran tersebut penting untuk mendorong meningkatnya ketepatan akurasi hasil penelitian yang diperoleh.

\section{DAFTAR PUSTAKA}

Alfi Shohreh, dan Safarzadeh Mohammad Hossein. 2016. Effect of Capital Structure and Liquidity on Firm Value. IJABER Volume 14 Number 14. 
Jurnal Manajemen dan Kewirausahaan, Volume 9, Nomor 3, September 2018

ISSN 2086-5031

E-ISSN 2615-3300

DOI 10.31317

Arif Ahmed, Ahmed Nauman Aness. 2012. Liquidity Risk And Performance of Banking System. Financial Regulation and Compliance, Vol. 20 Iss 2 pp. 182 - 195

Astuti Pendria Ade dan Efni Yulia. 2015. Pengaruh Kesempatan Investasi, Leverage Terhadap Kebijakan Dividend an Nilai Perusahaan Pada Perusahaan Manufaktur yang Terdaftar di Bursa Efek Indonesia. Jurnal Tepak Manajemen Bisnis Volume VII No 3 September 2015

Astriarini Fuji Eno. 2014. Pengaruh Kepemilikan Manajerial, Leverage, Profitabilitas, Ukuran Perusahaan dan Investment opportunity set Terhadap Nilai Perusahaan. Ejournal Fakultas Ekonomi Jurusan Ekonomi Universitas Negeri Padang, Padang.

Brigham \& Houston C Gapensky. 2011. Fundamentals of Financial Management. Tent Edition. Pearson.

Darmasita. 2012. Pengaruh Likuiditas, Leverage dan Kebijakan Dividen Terhadap Nilai Perusahaan Pada Perusahaan Manufaktur di Bursa Efek Indonesia. Jurnal Manajemen Bisnis Volume 12 Nomor 2. Universitas Diponegoro, Semarang.

Hasnawati Sri. 2005. Dampak Set Peluang Investasi Terhadap Nilai Perusahaan Publik di Bursa Efek Indonesia. JAAI Volume 9 No 2 Desember 2005 Hal $117-125$
Harmono. 2011. Manajemen Keuangan Berbasis Balanced Scorecard Pendekatan Teori, Kasus, dan Riset Bisnis, Edisi kesatu. Bumi Aksara, Jakarta.

Hair, Jason J Babin, Steven Andrew. 2010. Multivariate Analysis $5^{\text {th }}$ Edition. Mc Graw-Hill, Irwin.

Irawan Rudi. 2016. Perkembangan Pasar Modal Indonesia dari Waktu ke Waktu. www.kompas.com/bisnisinvestasi

Jogiyanto. 2009. Dasar Dasar Pasar Modal (Teori dan Aplikasi) Edisi V. BPFE, Yogyakarta.

Kasmir. 2008. Dasar Dasar Manajemen Keuangan. Edisi IV. Salemba Empat, Jakarta.

Mabruroh Vicky, Riswan dan Sri Lesari. 2017. Pengaruh Price earning ratio, Leverage, Dividen Payout Ratio, Profitabilitas dan Cash Holding Terhadap Nilai Perusahaan Pada Perusahaan Non Keuangan yang Terdaftar Dalam Indeks LQ 45. EJurnal Fakultas Ekonomi dan Bisnis Universitas Jenderal Sudirma, Purwokerto.

Martono dan Agus Harajito. 2011. Manajemen Keuangan Edisi Kedua. Cetakan Pertama. Penerbit Ekonisia, Yogyakarta.

Program Studi Manajemen Fakultas Ekonomi Unitas Padang 
Jurnal Manajemen dan Kewirausahaan, Volume 9, Nomor 3, September 2018

ISSN 2086-5031

E-ISSN 2615-3300

DOI 10.31317

Mardiyanto Lukman. 2009. Akuntansi Keuangan Lanjutan. Andi, Surabaya.

Nugraha Muhammad Aditya. Pengaruh Peluang Investasi, Pertumbuhan Terealisasi dan Kebijakan Dividen Terhadap Nilai Perusahaan (Studi Empiris Pada Perusahaan LQ 45 di Bursa Efek Indonesia). Skripsi Fakultas Ekonomi dan Bisnis Universitas Negeri Lampung.

Palepu Healy, 2009. Corporate Financial Statement. Wiley. Pearson.

Permanasari. 2017. Faktor Faktor yang Mempengaruhi Price earning ratio Pada Perusahaan Manufaktur di Bursa Efek Indonesia. Jurnal Bisnis dan Akuntansi Volume 5 Nomor 2.

Putra Adi AA Nugrah Dharma dan Lestari Vivi Putu. 2016. Pengaruh Kebijakan Dividen, Likuiditas, Profitabilitas dan Ukuran Perusahaan Terhadap Nilai Perusahaan. E-Jurnal Manajemen Unud Vol 5 No 7

Putrid Yaliana, dan Chabachip. 2013. Pengaruh Investment opportunity set dan Ukuran Perusahaan Terhadap Price earning ratio Pada Perusahaan Manufaktur di Bursa Efek Indonesia. Jurnal Akuntansi Keuangan Volume 4 Nomor 2.

Pradana Saputra. 2016. Panduan Investasi di Bursa Efek Indonwsia. www.idx.com/document
Prama Saputra. 2013. Pengaruh Investment opportunity set dan Profitabilitas Terhadap Price earning ratio Pada Perusahaan Manufaktur di Bursa Efek Indonesia Jurnal Ekonomi dan Bisnis Volume 4 Nomor 2.

Raham Abdul. 2017. Geliat Pasar Modal Indonesia. Artikel Pasar Modal. www.idx.com/article

Ross, William, Jeff. 2010. Coorporate Financial Statement. Edisi Indonesia. Gramedia Pustaka, Jakarta.

Saputra Mohamad, Ridwan dan Yuliani Irawati. 2017. Faktor Faktor yang Mempengaruhi Price earning ratio Pada Perusahaan Go Publik di Bursa Efek Indonesia. Jurnal Akuntansi dan Keuangan Volume 12 Nomor 2.

Saputro, Adi Akhmad dan Lela Hindasah. 2007. Pengaruh Kebijakan Pendanaan dan Profitabilitas Perusahaan Terhadap Set Kesempatan Investasi (IOS). Jurnal Akuntansi dan Investasi, VII (1): 58-71.

Santoso Singgih. 2012. Analisis Multivariate dengan Menggunakan SPSS 19.0. Gramedia Pustaka, Jakarta.

Sartono Agus. 2010. Dasar-dasar Perbelanjaan Perusahaan. Badan Penerbit Universitas Gajahmada, Yogyakarta.

Sembiring Yuliana, dan Pakhpahan. 2010. Pengaruh Kebijakan Dividen Terhadap Nilai Perusahaan (Studi 
Jurnal Manajemen dan Kewirausahaan, Volume 9, Nomor 3, September 2018

ISSN 2086-5031

E-ISSN 2615-3300

DOI 10.31317

Empiris Pada Perusahaan Manufaktur di BEI). Jurnal Ekonomi dan Bisnis Volume 4 Nomor 2.

Senata Magge. 2015. Pengaruh Kebijakan Dividen Terhadap Nilai Perusahaan yang Tercatat Dalam Indeks LQ45 Bursa Efek Indonesia. Jurnal Wira Ekonomi Mikroskil Volume 6 Nomor 01.

Suryaputri Widya dan Astuti Puji. 2003. Faktor Faktor yang Mempengaruhi Nilai Perusahaan. Jurnal Ekonomi dan Keuangan Volume 4 Nomor 2. Universitas Diponegoro, Semarang.

Tandelilin, Eduardus. 2010. Analisis Keputusan Investasi. BPFE, Yogyakarta.

Winarno Wing. 2009. Analisis Multivariate dengan Menggunakan Eviews. Cetakan 5. Salemba Empat, Jakarta.

Zooneld. 2017. Peranan Sektor Manufaktur Bagi Kemajuan Bursa Efek Indonesia. Artikel www.kompas.com/financial

Program Studi Manajemen Fakultas Ekonomi Unitas Padang 